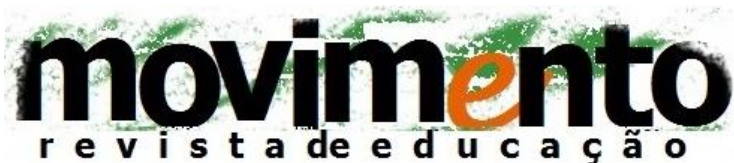 \\ faculdade de educação - programa de pós-graduação em educação \\ universidade federal fluminense \\ issn 2359-3296 \\ ano 3 número $4-2016$
}

\section{REDES EDUCATIVAS, CURRÍCULOS E IMAGENS: conversas com o filme Os Companheiros, de Mario Monicelli}

\author{
Joana Ribeiro dos Santos 1 \\ Sonia Maria Santos Pereira da Rocha² \\ Érika Arantes ${ }^{3}$
}

\section{Resumo}

Há currículos fora dos espaçostempos escolares? Tal questão será pensada a partir do diálogo com Alves (2012) e Oliveira (2012), onde uma defende que não há currículos fora dos espaçostempos escolares, enquanto a outra afirma que existem e são "currículos da vida cotidiana". Contribui com nossa discussão o filme "Os Companheiros", de Mario Monicelli, e as experiências vividas nos movimentos dos profissionais de educação no Rio de Janeiro, em 2013, 2014 e neste ano de 2016, uma vez que compreendemos que estes formam nossas tantas redes de conhecimentossignificações cotidianas.

Palavras-chave: Currículos; Cotidianos escolares; Movimentos grevistas.

\section{RESUMEN}

Nos preguntamos se hay currículos afuera los espaciostiempos escolares. Este asunto será pensado desde un diálogo con Alves (2012) y Oliveira (2012), en el que una defiende que no hay currículos afuera los espaciostiempos escolares, mientras la otra declara que existen y son "currículos de la vida cotidiana". Contribui para nuestra discusión el filme "Os Companheiros", de Mario Monacelli, y las experiencias vividas en los movimientos de los profesionales de educación de Rio de Janeiro, en 2013, 2014 y ahora en 2016, una vez que entendemos que estas forman nuestras redes de conocimientossignificaciones cotidianas.

Palabras clave: plan de estudios, cotidiano de la escuela; huelgas;

\footnotetext{
${ }^{1}$ Mestre em Educação (UERJ). Doutoranda em Educação (UERJ). Professora de História das redes municipal e estadual do Rio de Janeiro. Membro do GRPESQ "Currículos, redes educativas e imagens". joana.santos@rioeduca.net

2 Mestranda em Educação (UERJ). Professora da rede estadual do Rio de Janeiro membro do GRUPESQ "Currículos, redes educativas e imagens".srocha54@hotmail.com

3 Doutora em História (UFF). Professora da Universidade Federal Fluminense. Membro do GRPESQ “Currículos, redes educativas e imagens”. ebarantes35@gmail.com
} 


\section{INTRODUÇÃO}

Quantas experiências de aprendizagemensino vivenciamos todos os dias? Quantos espaçostempos ${ }^{4}$ frequentados por nós contribuem para que criemos conhecimentossignificações? Nós, que compreendemos que os saberesfazeres são tecidos cotidianamente em redes educativas, sabemos que a criação de conhecimentossignificações se dá a todo momento, a partir de experiências variadas, na relação com praticantespensantes 5 (OLIVEIRA, 2012) diversos e em todos os espaçostempos.

Alves (1999) aponta em um de seus textos que, na segunda metade do século XX, alguns movimentos passaram a questionar a forma hegemônica de "construir" conhecimento, propondo o que seria uma nova grafia para este processo pautada na ideia de rede. Dentre estes movimentos, a autora destaca três, a saber: mudanças no mundo do trabalho, onde relações mais horizontais e criativas irão contribuir para a crítica à ideia de racionalidade, e as disciplinas tradicionais que a legitimaram, como única forma de aquisição de conhecimentos; os processos desenvolvidos pelos novos campos de saber, como a informática, que rompem com a ideia de que existem, unicamente, conhecimentos ordenados, lineares e hierarquizados, que são aqueles criados pelas ciências; e a contestação da racionalidade como único fator responsável pelas contribuições da Modernidade, devendo dividir este mérito também com as criações cotidianas dos seres humanos. Alves afirma, então, que

[...] a linearidade e a hierarquização dão lugar a "múltiplas conexões e interpretações produzidas em zonas de contatos móveis" (LEVY, 1993). Isto tudo corresponde a um número imenso de caminhos

\footnotetext{
${ }^{4}$ Ao longo do texto, utilizaremos alguns termos unidos e em itálico por acreditarmos que são indissociáveis. Escrevemos espaçostempos, por exemplo, por compreendermos que se existem múltiplos espaços e múltiplos tempos - e por isso o plural que usamos - esses não podem ser pensados separadamente.

${ }^{5}$ Oliveira (2012) - coerente com o pensamento de Certeau que chama aos que agem nos cotidianos de 'praticantes' nos indicando que criam, permanentemente, pensamentos em suas ações - criou esta forma que nos parece muito mais completa: praticantespensantes.
} 
possíveis. A grande diferença da grafia em árvore é que a grafia em rede é escrita a partir da consideração de um valor diferente, o da prática social (LEFEBVRE, 1983). Trata-se, assim, de dar à prática a dignidade de fatos culturais e de espaço de criação de conhecimentos, que não são "tecidos" na teoria e que são importantes, para os homens, como os conhecimentos que nesta são "construídos". (ALVES, 1999, p.94)

Desta forma, a grafia em rede valoriza as práticas cotidianas, as vivências do dia a dia, como parte da tessitura ${ }^{6}$ de conhecimentossignificações, como criação e não apenas reprodução. O questionamento em torno da herança hegemônica moderna de conhecimentos baseados na grafia em árvore, ou seja, linear, hierarquizado, fragmentado, tendendo às especializações e visando a dar frutos específicos, simboliza o rompimento com a dicotomia entre teoria e prática, onde a primeira estava ligada aos espaços formais de produção de conhecimentossignificações e a segunda, ligada às práticas cotidianas. Estas últimas estariam associadas à reprodução dos conhecimentos hegemônicos ou a práticas menores, reduzidas ao título de "senso comum" e que deveriam ser superadas, pela criação de "conhecimentos verdadeiros", surgidos nos lugares de poder.

Assim, a imagem da árvore vai partilhar espaçostempos com a imagem da rede, que se expande para direções diversas, não possui ponto de partida, caracterizase por um emaranhado de fios que não se sobrepõem ou se superam, embora não estejam resguardadas das relações de poder. Alves continua dizendo que

[...] para todos esses, e nos demais setores da vida humana, se desenvolve a certeza e o sentimento de que a informação, sua circulação democrática ou o seu domínio, está na base da tessitura do contemporâneo - seja este considerado como uma nova fase do modernismo (TOURAINE, 1992; HARVEY, 1993; JAMESON, 1994), seja como uma outra realidade, e então chamado pós-modernismo. Assim, de maneira crescente, cada vez menos estranha e muitas vezes assustadora, vão sendo criadas redes (radiofônicas, televisivas, computacionais, contra a fome, dos sem-terra...) que ocupam as preocupações cotidianas dos homens e mulheres de todas as idades, mesmo aqueles aos quais o acesso é impedido, por motivos

\footnotetext{
${ }^{6}$ Compreendendo que os conhecimentossignificações são tecidos e não construídos, falaremos ao longo do texto em tessitura destes conhecimentossignificações, termo usado por Nilda Alves e referente à articulação de sons na composição musical.
} 
econômicos, políticos, religiosos etc. (LEFEBVRE, 1992). Tudo isso popularizou um termo - rede - que está, hoje, no âmago da nova forma de se compreender como se cria o conhecimento ${ }^{7}$, em todas as áreas de atividades humanas - das ciências aos movimentos sociais, do mundo do trabalho à comunicação social. (ALVES, 1999, p.97)

No emaranhado destas redes de conhecimentossignificações há aquelas que podemos identificar como redes educativas, que estão para além dos muros das escolas, mas também nelas, nas universidades, em outras instituições de aprendizagemensino, em muitos outros espaçostempos das vivências humanas. Assim, é difícil, quase impossível, determinar quais redes não são educativas, pois, uma vez que superamos a ideia de aprenderensinar apenas ligada aos saberes hegemônicos, toda e qualquer relação direta ou indireta entre praticantespensantes (OLIVEIRA, 2012), toda partilha de saberesfazeres tece 0 que pode ser pensado como redes educativas. Logo, são múltiplas estas redes e podem ser percebidas, como já foi dito, no dentrofora das escolas, no bairro, nos ambientes religiosos, nos arranjos familiares, nos locais e relações de trabalho, nos programas de rádio e televisão, no contato com obras de artes, nos usos (CERTEAU, 1994) e modos de estar nas redes sociais etc.

Vale lembrar que a criação de conhecimentos se dá sempre junto à criação de significações sobre como ele foi criado, se explicita, para que serve etc. (MATURANA, 2001). Por isto, escolhemos escrever, ao longo deste artigo, o termo conhecimentossignificações, junto e em itálico, como vem sendo usado (CERTEAU, 1994) por Alves em suas pesquisas mais recentes nos/dos/com os cotidianos escolares. Além disso, a própria imagem das redes nos ajuda a pensar a tessitura destes conhecimentossignificações como uma criação cotidiana, não hierarquizável, não linear e não dicotômica.

Partindo dessa concepção quanto à criação de conhecimentossignificações em múltiplas redes educativas, gostaríamos de apresentar a questão que nos motiva a escrever este artigo e que desejamos discutir ao longo do mesmo. Se a

\footnotetext{
7 No presente, a autora referida pluraliza este termo (conhecimentos) e 0 indica ligado às significações criadas com eles. Escreve então: conhecimentossignificações.
} 
tessitura de conhecimentossignificações se dá em redes, podemos considerar que há currículos nos diversos espaçostempos nos quais aprendemosensinamos? Há currículos, assim, fora dos espaçostempos escolares?

Em um primeiro momento, nos pareceria coerente com a ideia de tessitura de conhecimentossignificações em redes afirmar que há diversos currículos nos variados espaçostempos nos quais vivenciamos experiências cotidianas de aprendizagemensino. Mas estas experiências de aprenderensinar se organizariam em currículos ou se dariam de outras formas?

\section{Conversando com Alves e Oliveira sobre currículos}

Oliveira (2012) e Alves (2012) chamaram atenção para alguns aspectos deste debate. A primeira defende a existência do que chama de "currículos da vida cotidiana", dizendo que estes podem ser explícitos ou ocultos. A autora se vale das propagandas televisivas para dizer que: "outras situações cotidianas e artefatos culturais diversos nos colocam diante de valores, ideais, compreensões de mundo e conhecimentos múltiplos, constituindo-se como currículos da vida cotidiana" (OLIVEIRA, 2012, p.170). A autora destaca, também, a ideia de 'currículo oculto' para questionar a hegemonia dos processos de aprendizagemensino, demonstrando que aprendemos para além do que os currículos oficiais desejam transmitir. No entanto, identificar a existência de currículos ocultos nas escolas, ou seja, reconhecer que há aprendizagemensino naquilo que não é dito, nos momentos de lazer entre os estudantes, em atividades que não são oficialmente reconhecidas enquanto momentos de aprendizagem, nos leva a insistir na questão: existem currículos fora das escolas?

Oliveira afirma, ainda, que: 
assim, é considerando a vida cotidiana como fonte de aprendizagem e de tessitura de conhecimentos que permito-me assumir, aqui, a ideia da existência de currículos fora dos espaços escolares, recorrendo à noção de redes educativas formulada por Nilda Alves (ALVES, 2010) como modo privilegiado de compreensão dos processos de tessitura de conhecimentos que vivenciamos em nossos contatos com diferentes espaçostempos de práticas sociais. (OLIVEIRA, 2012, p.175)

Embora Oliveira se baseie nas noções criadas por Alves para defender a existência de currículos fora dos espaços escolares, esta última defende uma ideia diferente. Alves (2012) afirma que formamos e somos formados em inúmeras e complexas redes educativas, mas isto não significa que cada uma destas redes tenha seu próprio currículo. Assim, Alves defende que fora dos espaçostempos escolares não há, ou ainda não há, currículos, já que considera que este foi um termo criado para designar 0 trabalho com conhecimentossignificações nos espaçostempos escolares.

Se ambas concordam que os conhecimentossignificações são tecidos em redes educativas nos múltiplos cotidianos e no dentrofora das escolas, discordam na resposta à questão que trouxemos para iniciar o debate. Enquanto Oliveira considera os processos de aprendizagemensino tecidos fora das escolas como "currículos da vida cotidiana", Alves os considera o "outro do currículo", aquilo com que os currículos oficiais devem dialogar, uma vez que nossas redes estão a todo momento se relacionando com os espaçostempos escolares.

Alves diz que há "currículos em redes" em todas as escolas, mas que não há nenhum currículo oficial em redes, pois uma característica inerente às redes é seu estado caótico, imprevisível, marcado pelas ações, pelas táticas dos praticantespensantes e que, por isto mesmo, não podem ser controlados, previamente organizados como currículos. Nas palavras da autora:

[...] entendo que os currículos são assunto de espaçostempos escolares e fora deles não existe, e considero, ainda que aos currículos oficiais é impossível que incorporem os modos caóticos de tessitura dos conhecimentos e significações cotidianas, pois não conseguirão nunca 'determiná-los', pois o caos é indeterminável e aparece sempre no aleatório singular do acontecimento. No entanto, 
é preciso compreender que vamos tendo que incorporar o que se passa em redes educativas fora das escolas como o que poderíamos chamar de "o outro dos currículos", pois sua visibilidade crescente vem exigindo diálogos variados: ora são as mídias que nos exigem criação de ações curriculares novas; ora os movimentos sociais aparecem e exigem a incorporação de novos conteúdos e novas ideias, e assim por diante... (ALVES, 2012, p. 228)

É possível perceber neste diálogo que as duas autoras seguem caminhos muito próximos, pois ambas reconhecem a existência de múltiplas redes educativas e que as mesmas estão em contato com as escolas, daí falarmos em dentrofora das escolas, pois são indissociáveis. As autoras também reconhecem a existência de variados currículos dentro dos espaçostempos escolares, opondose apenas ao compreender diferentemente se há ou não currículos nas redes educativas que estão fora destes espaçostempos.

A discussão segue e as autoras se valem do próprio termo 'currículo' para seguir sua argumentação. Alves nos diz que 'currículo' foi um termo

[...] forjado para explicar, de modo variado é verdade, as articulações possíveis, considerando tanto os modos de agir de praticantespensantes envolvidos em processos escolares, em suas relações dentrofora das escola, sejam culturais econômicas, políticas ou outra natureza qualquer, como conteúdos propostos ou desenvolvidos nesses mesmos processos. (ALVES, 2012, p. 234)

A autora complementa dizendo: 'ou seja, esta é uma 'invenção' da literatura anglo-saxã para explicar processos escolares e nenhum outro" (ALVES, 2012, p.234).

Oliveira também destaca que o termo 'currículo' se refere historicamente "à organização de processos intencionais de ensino, a serem desenvolvidos em 'espaçostempos' escolares, com objetivos e procedimentos definidos" (OLIVEIRA, 2012, p. 175). Assim como Alves, a autora complementa sua ideia, mas dirigindo-se para uma conclusão diferente:

[...] assim, mesmo se a tradição do campo de estudos e pesquisas no campo do currículo não autoriza, em virtude da identificação entre a 
escola e o currículo, entendo que é possível pensar em currículos para além dos espaços escolares, na perspectiva das redes educativas nas quais nos inserimos e que nos formam, nos múltiplos enredamentos que nelas se tecem e que nos permitem tecer múltiplas e diferenciadas redes de conhecimentos. (OLIVEIRA, 2012, p.175)

Tentando indicar os aspectos centrais da discussão entre as autoras e facilitar o caminho que desejamos desenhar neste texto, podemos dizer que Oliveira (2012) defende a existência de currículos cotidianos nas diversas redes educativas que reconhecemos nos tantos dentrofora das escolas. Alves (2012) discorda desta ideia, pois acredita que os conhecimentossignificações nos processos curriculares se apresentam de modo sistematizado e que isto não ocorre nas demais redes educativas, nas quais os conhecimentossignificações circulam de modo caótico. Assim, Alves apresenta-nos uma alternativa para o pensamento. Ao afirmar que há, no entanto, "pedagogias" nas demais redes educativas, como explicitado abaixo:

[...] assim, eu diria que não existem currículos nas redes educativas que trançam seus conhecimentos e significações com os currículos escolares. No entanto, eu reconheço existirem "pedagogias" as/nas redes educativas. Entendo, que os processos de "educar" nessas redes exigem diferentes formas de articular conhecimentos e significações próprios, têm características próprias nas relações entre os que nela atuam quem sabe e quem não sabe o que é preciso fazer em certas ocasiões; quem pode melhor falar neste ou naquele momento; "quem tem a última palavra"... Isso tudo possibilita pensar que as pedagogias específicas a cada uma delas atuam nos processos educativos que dentro delas se dão. (ALVES, 2012, p. 229)

Gostaríamos, agora, de continuar essa conversa trazendo para o diálogo algo que é caro ao grupo de pesquisa 'Currículos, redes educativas e imagens', do Laboratório Educação \& Imagem, da Universidade do Estado do Rio de Janeiro (UERJ) e do qual fazemos/fizemos parte, que são as imagens. De que forma as imagens, tão presentes em nossos cotidianos, contribuem para a tessitura de currículos e para a pensarmos a questão central deste texto?

\section{Currículos e Imagens}


Vivemos em uma sociedade onde cada vez mais a imagem está presente em nossos cotidianos e "nos moldando". A fotografia, o cinema e a televisão fazem parte de nossas vidas e são fios que ajudam a tecer nossas redes de conhecimentossignificações. O grande impacto da internet e das redes sociais contribuem ainda mais para a divulgação de imagens, que agora podem ser compartilhadas com facilidade com apenas um clique, articulando-se aos fios na tessitura das redes.

Essas imagens estão no mundo, como entendemos que as escolas estão no mundo, fazendo parte das relações que tecemos em nossas redes educativas. De várias formas a chamada 'sociedade da comunicação', na qual as imagens ocupam um lugar privilegiado, é vivenciada nos cotidianos das escolas. Portanto, é de grande importância que pensemos sobre como as imagens possibilitam as inúmeras tessituras de conhecimentossignificações pelas quais docentes e discentes aprendemensinam, formando currículos com imagens, em processos pedagógicos múltiplos.

Visitando as análises de Boris Kossoy, compreendemos os desdobramentos que as imagens exercem em nossas vidas. Kossoy nos explica que

[...] algumas imagens nos levam a rememorar, outras a moldar nosso comportamento; ou a consumir algum produto ou serviço; ou a formar conceitos ou reafirmar pré-conceitos que temos sobre determinado assunto; outras despertam fantasias e desejos. (KOSSOY, 2002, p.40)

Para Fishman (2008), que pensou sobre os usos das imagens em pesquisas educacionais, ainda existe uma dependência do texto escrito entre os pesquisadores da área de educação e a tendência geral é que se desconsidere as imagens como possibilidade de pesquisa sem que as mesmas venham junto com um texto - como uma legenda em uma fotografia, por exemplo (p.112). Isto nos confirma Machado (2001) ao dizer que "parte considerável do mundo intelectual ainda se encontra petrificada na tradição milenar do iconoclasmo" ( $p$. 32). A dificuldade de incorporar a imagem como possibilitadora de compreensão dos espaçostempos educacionais vem sendo superada, no entanto. 
Se para muitos a imagem não tem importância, precisamos lembrar que "parte da humanidade aprendeu não apenas a conviver com as imagens, mas também a 'pensar com as imagens' e a construir com elas uma civilização complexa e instigante" (MACHADO, 2001, p.32).

Assim, pesquisadores na área de educação também romperam esta barreira que coloca em lados opostos imagem e texto, trabalhando com ambos em pesquisa de currículo e em diversas outras correntes de pesquisa no campo educacional, assim como as pesquisas nos/dos/com os cotidianos, trabalhando com os currículos escolares.

Dentro dessa corrente, Nilda Alves, há alguns anos, levanta a importância das imagens na tessitura de conhecimentossignificações e que os currículos escolares são compostos, também, por imagens: imagens que vemos nas reportagens jornalísticas, no cinema, na TV, na internet, imagens de docentes e discentes que se entrelaçam com a escola que fazemos, entre tantas outras. Todas essas informações imagéticas - e que são também narrativas - estão nas redes educativas tecidas nos tantos dentrofora ${ }^{8}$ das escolas. Por isso, partimos da ideia de que nos cotidianos, em suas múltiplas redes, são desenvolvidos processos permanentes de criação de conhecimentossignificações, nos quais as imagens e as narrativas têm papel relevante. (ALVES, 2007)

Mas como pensar em currículo de imagens no cotidiano escolar? Senhores do momento oportuno (kairós), os professores se utilizam das oportunidades criadas pelas circunstâncias cotidianas. Como as nossas imagens da memória e histórias pessoais estão entrelaçadas nas nossas formas de aprenderensinar, uma foto de família ou da escola, uma imagem no jornal, uma cena de novela, um filme que passou na TV ou no cinema, tudo pode ser um mote para uma conversa, um fio para tecer redes de conhecimentossignificações. Professores,

\footnotetext{
${ }^{8}$ Dentrofora é outro termo que usamos unindo palavras por acreditarmos que os espaçostempos das escolas e os que estão fora delas estão sempre em relação.
} 
em seus cotidianos, criam permanentemente suas táticas (CERTEAU, 1994) para tomarem partido da ocasião, como fazem todos os praticantespensantes (OLIVEIRA, 2012) dos cotidianos.

No entanto, é importante ressaltar que tecer currículos com imagens não é apenas usá-las como ilustração, para "demonstrar" visualmente o que estamos dizendo. Ressaltamos, aqui, que os praticantespensantes das escolas não são passivos à recepção destas imagens e cada um formulará questões a partir daquilo que estas criam nas redes educativas que formamos e nas quais somos formados.

Assim, quando assistimos um filme, por exemplo, temos nossas memórias acionadas e formulamos questões e ideias sobre ele a partir delas. No entanto, cada praticantepensante que assistem o mesmo filme, acionará suas memórias a partir de suas próprias redes educativas o que possibilita a formulação de diferentes perguntas - e respostas a estas. Kossoy resume bem o que estamos querendo dizer:

[...] essas imagens, entretanto, uma vez assimiladas em nossas mentes, deixam de ser estáticas; tornam-se dinâmicas e fluidas e mesclam-se ao que somos, pensamos e fazemos. Nosso imaginário reage diante das imagens visuais de acordo com nossas concepções de vida, situação socioeconômica, ideologia, conceitos e pré-conceitos (KOSSOY, 2002, p. 45).

Nas pesquisas nos/dos/com os cotidianos, as imagens e as narrativas são pensados a partir da ideia de 'personagens conceituais', formulada por Deleuze e Guattari (2010). Assim, nessas pesquisas, entendemos que 'personagens conceituais' podem ser compreendidos/usados como nos ensina Alves quando diz que

[...] em "conversas" permanentes com os diversos grupos de pesquisa que faziampensavam as pesquisas com os cotidianos - e estimulada pelas constantes perguntas de Antonio Carlos Amorim (Unicamp), sobre o que significavam as imagens (e as narrativas) nessas pesquisas - fomos levados, nas "conversas" de nosso grupo de pesquisa, a compreender as imagens e as narrativas como 
"personagens conceituais" (DELEUZE e GUATTARI, 1992), ou seja, como aquele que "fazemos falar e perguntar por nós", como Deleuze indica que Descartes faz com seu personagem "o Idiota". Ou seja, como o 'outro' com que 'conversamos' permanentemente, que nos vai colocando perguntas, que nos obriga a pensar para fazer caminhar 0 pensamento e com o qual criamos conhecimentossignificações com tudo o que vamos acumulando, organizando e articulando ao desenvolver as pesquisas. (ALVES e ANDRADE, 2013, pp.3-4)

No presente, trabalhando com o cinema, que nos permite unir imagens e sons, temos a possibilidade de trabalhar com sua imensa variedade de temáticas 0 que nos tem possibilitado estabelecer 'conversas', com diversos grupos de professores - em formação e em serviço - sobre os mais diversos assuntos, buscando articular as tantas questões que se apresentam a esses praticantespensantes em seu fazer curricular. Compreendendo, com Rincón (2002), que o audiovisual é um supermercado simbólico de estilos de vida para habitar esses tempos desalmados de razões, entendemos a potência do cinema e que sua incorporação à pesquisa que desenvolvemos constitui-se na possibilidade para se imaginar a existência, para se pensar numa história possível, para além da história existente, como propôs Santos (1998).

Para nós, o cinema se mostra uma possibilidade interessante em nossas pesquisas também pelo fato de que, através das narrativas criadas a partir dos filmes, é possível perceber as redes educativas em que são formados os praticantespensantes das escolas. Ao mesmo tempo que os filmes nos fazem reviver memórias, também passam a fazer parte de nossas memórias, se constituindo como mais um dos muitos fios que tecem nossas redes de conhecimentossignificações. Quanto às relações do cinema e das narrativas tecidas a partir deles com os currículos que praticamos nas escolas em que trabalhamos podemos dizer que, de algum modo, esses artefatos culturais influenciam os processos curriculares que desenvolvemos. É esta ideia que buscamos tecer melhor no próximo item, a partir de um exemplo.

REDES EDUCATIVAS E CURRículos: um trançado a partir do filme "Os companheiros" e das vivências nos movimentos grevistas 
Uma vez parte de um grupo de pesquisa que estuda cinema, suas imagens e sons, buscamos, ao ver e ouvir filmes, aspectos inerentes aos nossos cotidianos. Recentemente, vivenciamos movimentos em que tecemos conhecimentossignificações que trouxeram para nossas redes novos sentimentos, memórias, compreensões do vivido etc. Com e a partir das experiências cotidianas nos movimentos de greve dos professores das redes municipal e estadual do Rio de Janeiro nos anos de 2013 e 2014 e, mais recentemente, em 2016, tecemos outros fios em nossas redes e nos modificamos.

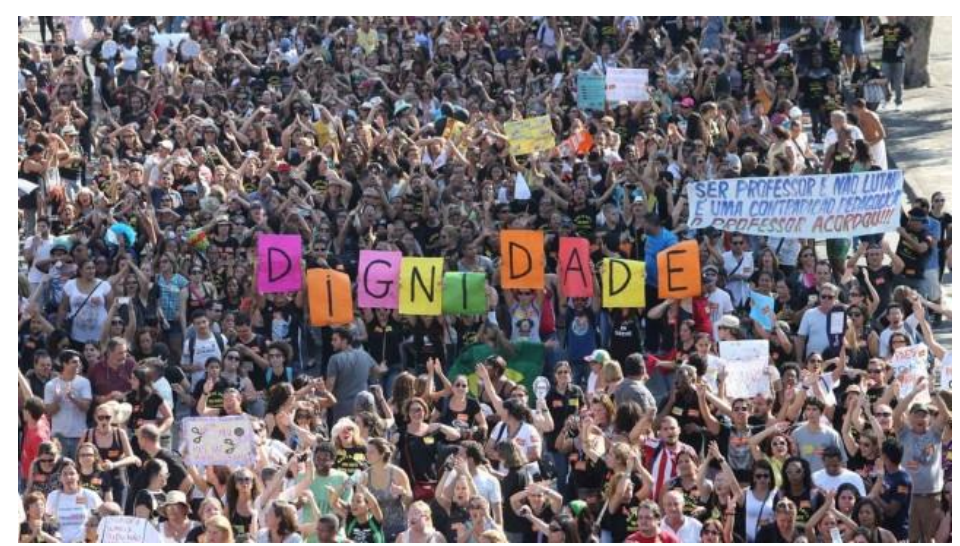

Imagem 1 - Movimento de professores. Fonte: Arquivo pessoal das autoras.

Foram muitas as novas aprendizagens, muitos os conhecimentossignificações tecidos. As vivências no sindicato, o aprendizado das pedagogias de uma luta trabalhista, a ocupação de espaçostempos públicos na rua, as novas memórias associadas aos espaçostempos da cidade, as reações com o que era dito e mostrado pelas diversas mídias que acompanharam o movimento, nossas experiências coletivas e os debates e contradições entre nós professores, as novas relações com as escolas e os estudantes etc.

Pensando na discussão que desejamos propor a partir deste texto e em todos os conhecimentossignificações tecidos nos/dos/com os movimentos que vivemos, escolhemos um filme que contribuiu para a criação de diversas narrativas a partir de nossas memórias. Essas narrativas e as imagens do filme 
dialogaram intensamente com as nossas experiências cotidianas e com a nossa conversa neste texto.

O filme "Os Companheiros", de Mario Monicelli, foi produzido em 1963, em meio ao aumento dos movimentos sociais que eclodiriam na Europa na década de sessenta. Ou seja, foi tecido em meio à efervescência política e social do período e remonta à uma crise política e social e ao desenvolvimento do movimento sindical na Europa, antes da Revolução Russa de 1914. O local escolhido para ser o desenvolvimento da trama é a cidade de Turím, na Itália, e o cenário principal é uma fábrica de tecidos. A fome é a linha que costura toda a história.

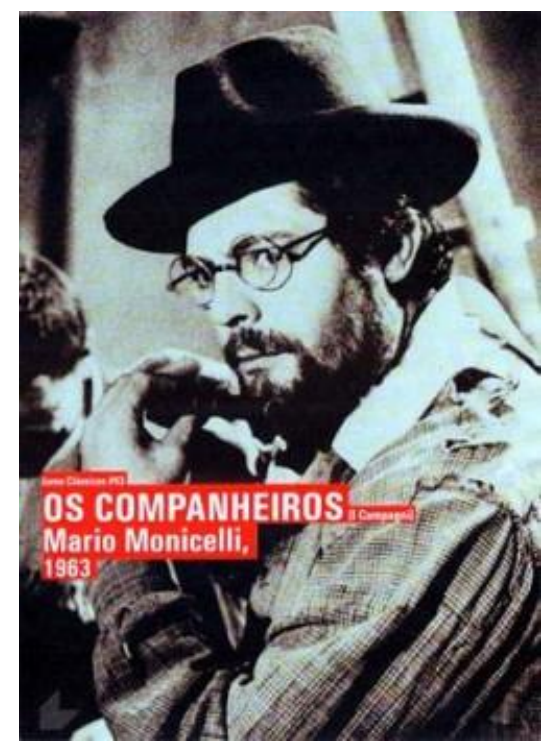

Imagem 2 - Capa do filme Os Companheiros. Disponível em: http://averdade.org.br/2011/09/os-companheiros/. Acesso em maio/2016.

O filme é o recorte de um mês na vida de operários da fábrica e cobre todo o período de greve destes trabalhadores. O assunto é a sobrevivência alinhavada pelo analfabetismo e a tábua de salvação, pela condução da história, seria a educação. Porém, o próprio professor Giuseppe Senigalia (Marcelo Mastroianni), um "agitador" que está fugindo de Gênova por ferir um policial, tem como companheira, além da fome, a falta de teto. 


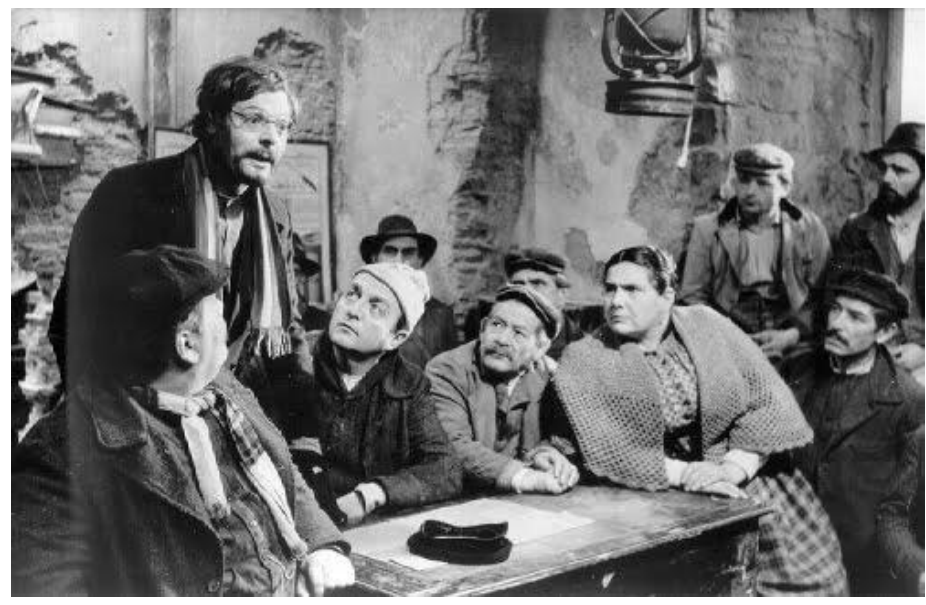

Imagem 3 - Cena do filme Os Companheiros. Disponível em: https://imagensamadas.com/tag/1960/. Acesso em maio/2016.

A sala de aula dos trabalhadores vira palco de assembleias por melhores condições de trabalho. Após a longa jornada de trabalho todos estão extenuados, mas encontram energia para irem à escola. Alguns dormem e o professor reclama que não aprendem. Não sabem ler, têm problemas para decodificar um bilhete.

O filme retrata os cotidianos desses trabalhadores do acordar à saída da fábrica, passando pela hora do almoço, em um total de quatorze horas de trabalho. Estão sempre sob vigilância, tanto durante o trabalho quanto na hora do almoço. $O$ responsável por esta vigilância, ou seja, o trabalhador encarregado de vigiar os outros, como ele, trabalhadores, é entre o grupo, o mais pobre.

Monicelli representou o registro dos acidentes de trabalho nas máquinas, que eram uma constante na época e um dos graves problemas trabalhistas no século XIX. Pôs em seu registro cinematográfico as coletas que os funcionários faziam para ajudar a manter a família dos acidentados e dos mortos em conflito com a polícia. 


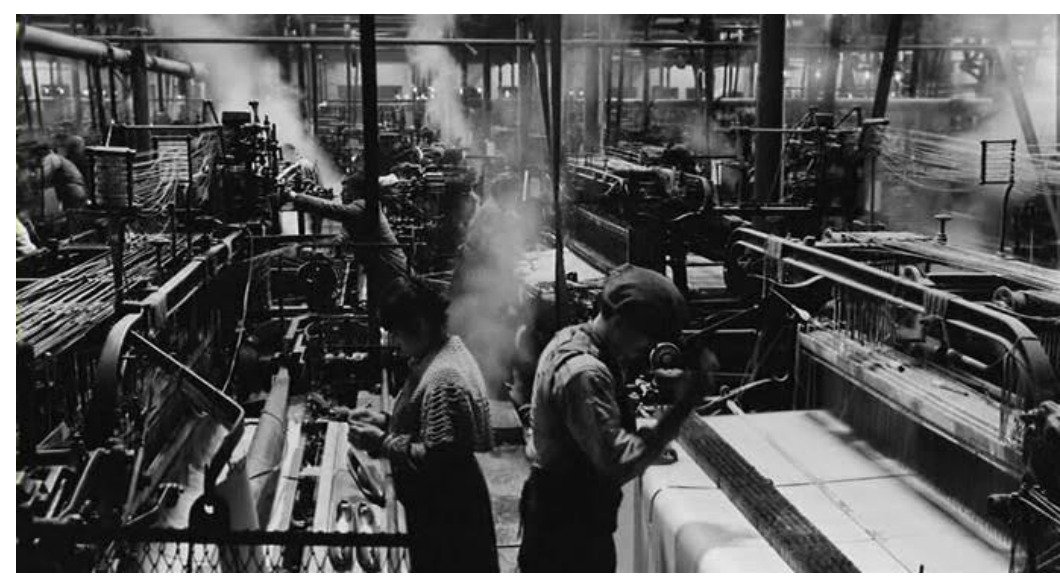

Imagem 4 - Cena do filme Os Companheiros. Disponível em: http://naufrago-dautopia.blogspot.com.br/2015/04/veja-no-blogue-o-melhor-filme-sobre-o.html. Acesso em maio/2016.

Em relação à educação, o professor, que era alguém letrado, era tão pobre ou mais que a maioria dos trabalhadores fabris. Vivia de favor com um deles e tinha dificuldades para se sustentar. Quando perguntado por que fazia aquilo - lutar por direitos! - já que tem estudo e não é como a maioria dali, ele responde: eu não sou como vocês.... não tenho família, nem amigos, nem quem me busque, a não ser a polícia (...) então por que fazer isso? (....) porque tenho ideias disparatadas.

Monicelli, que também foi o roteirista, coloca alguém muito específico para retratar a imagem de um professor, num contexto de quem não tem nada a perder, mas a quem também o conhecimento não deu o conforto nem a segurança que todos sonham. Mesmo assim, a educação ainda é tida como redentora. Homero, o menino que é arrimo de família, bate em seu irmão mandando-o estudar e diz: se você terminar como eu.... eu te mato.

A situação dos trabalhadores da fábrica de tecidos é comparada aos escravos de "Spartacus" que são citados pelo professor Senigalia, na última assembleia em que decidem que não voltarão ao trabalho e partem para enfrentar a polícia em praça pública. A aquisição de conhecimentos é, assim, todo o tempo associada à criação da ideia de cidadania e ao exercício dela.

O contexto tão rico de questões sociais do filme "Os Companheiros" nos possibilita pensar o que são as redes de conhecimentossignificações dos 
praticantespensantes, suas conexões educativas nos diversos espaçostempos que frequentam, independente de estar ou não na escola, e as diferenças entre os conhecimentos dos cotidianos, informais, e os conhecimentos organizados para serem trabalhados nas instituições educacionais.

Dentre as diversas redes educativas apresentadas no filme, gostaríamos de destacar as que são criadas na fábrica, na escola, no conjunto de moradias onde vive boa parte dos operários, na entrada da fábrica, onde ocorrem conflitos etc. Nestes diferentes espaçostempos se criam as redes educativas formadas pela família, pelas amizades, pelas relações de trabalho, pelo contato com os conhecimentos formais, pela sociedade como um todo e o que é exigido para participar desta, pelo contato mais próximo com os dois professores, pela solidariedade de alguns soldados e famílias que fazem doações aos operários, pelas disputas entre trabalhadores de cidades diferentes, pelas discriminações sociais, políticas e de gênero que marcavam o período e que podem ser discutidas ainda hoje etc. Todas estas redes educativas formavam aqueles operários e o professor e eram por eles formadas. Todas estas redes educativas criam conhecimentossignificações.

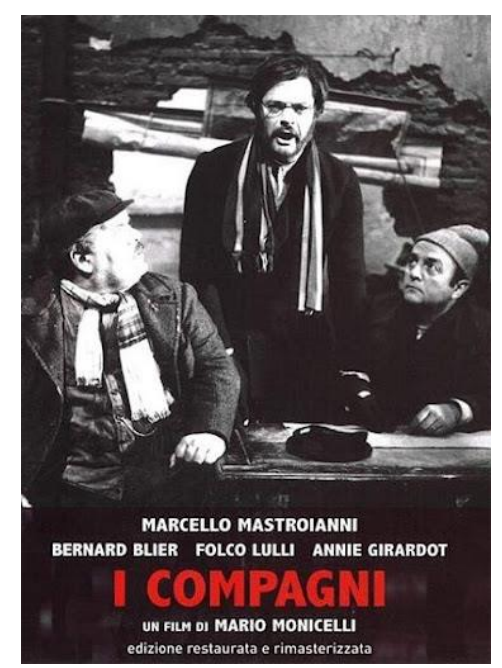

Imagem 5 - Divulgação do filme Os Companheiros. Disponível em: https://fernandonogueiracosta.wordpress.com/2013/02/28/os-filmes-de-minha-vida-faseuniversitaria-em-belo-horizonte-1971-1974/. Acesso em maio/2016. 
E quanto a nós? Quais redes educativas nos formam enquanto docentes e discentes das escolas públicas? Será que nossa formação é tecida apenas nos espaçostempos educacionais formais? Será que nossa formação se dá apenas nas salas de aula, sejamos docentes no exercício da profissão ou estudantes? Será que as redes educativas que nos tecem e que ajudamos a tecer coletivamente estão também no dentrofora das escolas públicas, universidades, cursos etc.? Será que estas não estão, por exemplo, nas assembleias dos profissionais da educação organizadas pelo sindicato ou, ainda, nas ruas, quando marchamos por melhorias na educação pública?

É neste sentido que chamamos o filme "Os Companheiros" para nossa conversa, pois acreditamos que sua narrativa nos auxilia, a partir da ação de nossas memórias, a pensar as vivências mais recentes nos movimentos grevistas dos profissionais da educação no Rio de Janeiro e como esta nos forma professorxs (assim escrito como forma de destacar que há um número maior de mulheres nesta profissão, embora o plural seja marcado com o morfema desinencial masculino). Assim como os operários do filme teceram conhecimentossignificações na sala de aula improvisada, nos corredores da fábrica, nos protestos que organizaram, transformando-se e transformando, mesmo que pouco aos nossos olhos, sua realidade, nós também aprendemosensinamos no movimento grevista.

RESGATANDO A Discussão: Há currículos fora da escola? Há currículos nos cotidianos dos movimentos sociais?

Até aqui, buscamos, a partir do entendimento de que são múltiplas as redes educativas que nos formam no dentrofora das escolas e outras instituições de aprendizagemensino, defender que nos formamos enquanto docentes também na participação de movimentos grevistas dos profissionais de educação, a exemplo dos vividos em 2013 e 2014 nas redes públicas municipal e estadual do Rio de Janeiro e, neste ano de 2016, também na mesma rede estadual. Porém, de forma insistente nos volta a tal questão: será que o filme e os movimentos 
grevistas citados nos ajudam a afirmar que existem currículos nos espaçostempos de trabalho, das ruas, das lutas trabalhistas etc.?

Buscando dar conta desta questão, voltemos às duas ideias sobre a existência curricular nos dentrofora dos espaçostempos escolares cogitadas por duas autoras que trouxemos para nossa conversa: Alves e Oliveira.

A última defende a possibilidade da existência de currículos para além da escola e postula a noção de currículo oculto como: "aquilo que se aprende pelo meio dos não ditos, dos implícitos, dos comportamentos e atitudes" (OLIVEIRA, 2012, p.169). Já Alves nos diz, fundamentando com as questões teóricometodológicas, que a construção de conhecimentos oficiais é preconizada por um modelo dicotômico, pela produção de conhecimentos-verdade na finalização de processos de pesquisas, pela hierarquização de conhecimentos que, por vezes, negam as significações produzidas pelas vivências cotidianas, pela postulação de uma forma privilegiada de produzir conhecimentos - a das ciências - pela cogitação da neutralidade na criação do conhecimento científico e da admissão da racionalidade como único aspecto no desenvolvimento e criação de conhecimentos. Tudo isso, segundo esta autora inviabiliza, pelo menos por enquanto, a possibilidade de se cogitar a existência de "currículos oficiais em redes".

Mesmo se entendermos que os conhecimentos e significações tecidos nas redes educativas são potentes na compreensão do mundo e o quanto são importantes para a convivência entre os seres humanos, as relações familiares, de vizinhança, de amizade, de trabalho e a formação de núcleos de reivindicações políticas, elas não têm, necessariamente, a ver com conhecimentos organizados sistematicamente.

Lembramos que, segundo Alves (2012), não existem currículos nas redes educativas e sim "pedagogias" das/nas redes educativas com formas diferentes de articulação de conhecimentos e significações próprias. No entanto, é necessária a compreensão de que, o que acontece fora da escola está presente 
como o "outro" no currículo atravessando-o como espaçostempos de tessitura de múltiplos componentes, de disciplinas, movimentos caóticos e táticas dos praticantespensantes. Logo, "as práticasteorias pedagógicas que vemos/fazemos acontecer em cada uma das redes que formamos e nas quais nos formamos, vão ter sempre influência nos currículos praticadospensados_nas escolas" (ALVES, 2012, p.233).

Consideramos, assim, a partir do já visto, que os modos de relação de conhecimentossignificações nos currículos das escolas, de cunho histórico e oficial, que foram designados como disciplina, possuem conexão com o exterior e são carregados de transversalidades e atravessamentos com as redes educativas e que são modificados, na forma pedagógica, para caberem nos currículos escolares. Estes foram criados para explicar as articulações possíveis considerando modos de agir dos praticantespensantes e suas relações no dentrofora das escolas nos aspectos culturais, econômicos e políticos como conteúdos propostos ou desenvolvidos em meio ao processo educativo.

No entanto, neste momento nos vemos entre dois caminhos: se admitimos que os currículos só existem dentro das escolas, talvez estejamos compreendendo mal o espaçotempo imaginado da escola como aparece no filme de Monicelli. Nele as relações dentrofora da escola, como dentrofora da fábrica, são tão fortes que nos permitem perguntar: podemos falar de um só tipo de currículo - o escolar? Ou aqui caberia falar de currículos escola-fábrica-casa? Assim também, as experiências que adquirimos no movimento de professores envolvia tanto a escola, como o sindicato, como a rua. E aqui? Será que podemos falar em um currículo escola-sindicato-rua? Por outro lado, talvez falar em currículos no dentrofora dos espaçostempos escolares seja tentar enquadrar tais conhecimentossignificações tecidos nestes em esquemas próprios apenas dos espaçostempos escolares. Fazer este enquadramento poderia limitar a potência das redes de conhecimentossignificações que tecemos e nos tecem.

Talvez, para "solucionar" esta questão, seja necessário abrir mão da pergunta que nos fizemos desde o início da escrita deste texto. Mais do que responder se 
há ou não currículos fora dos espaçostempos escolares, é necessário valorizar, tanto a multiplicidade de currículos que existem dentro desses espaçostempos, como as diversas experiências de tessitura de conhecimentossignificações que se dão nas ruas, nos movimentos sociais, nas manifestações culturais, nos usos variados das mídias, nos movimentos de ocupação realizados pelos estudantes em suas escolas nos anos de 2015 e 2016 etc.

É pensando nesta mudança de olhar que chegamos ao fim desta conversa, concluindo que os conhecimentossignificações são criados nos tantos dentrofora das escolas e todas as situações cotidianas, experiências, movimentos, textos, imagens, sons etc. que nos atravessam ao longo da vida e se constituem como fios que vão nos tecendo e tecendo nossas redes educativas que com tantos vamos formando. Assim, nos aproximamos do pensamento de Alves no momento em que essas redes educativas não são consideradas por nós como currículo, que entendemos ser algo próprio das escolas. No entanto, caminhamos ao lado de Oliveira, ao estarmos certas da importância dessas redes tecidas para além dos espaçostempos escolares para a formação dos praticantespensantes das escolas.

Por isso, no filme "Os companheiros", o professor aprendiaensinava com as suas experiências cotidianas tecidas em espaçostempos diversos. Todo o vivido entrava junto com ele na sala de aula. Ao mesmo tempo, o que acontecia na sala de aula, mas também no movimento sindical, o afetava e o constituía, assim como nos afetou e nos constituiu nossas tantas experiências dentrofora das escolas.

Essas experiências incluem nosso cotidiano escolar, mas também nossos movimentos grevistas de 2013, 2014 e 2016 (e tantos outros movimentos dos quais fizemos parte), incluindo viagens que fazemos/fizemos, lutas que lutamos, mas também filmes que assistimos e sobre o qual conversamos e escrevemos... 


\section{REFERÊNCIAS}

ALVES, Nilda. Currículos em 'espaçostempos' não escolares isso existe? redes educativas como o outro em currículo. In: SANTOS, Lucíola Licínio de Castro Paixão; FAVACHO, André Márcio Picanço. Políticas e práticas curriculares: desafios contemporâneos. Curitiba. PR: CRV, 2012.

. Faz bem trabalhar a memória - criação de currículos nos cotidianos, em imagens e narrativas. In: ALVES, Nilda (org.). Redes Educativas e Currículos Locais. 1ed. Rio de Janeiro: Laboratório Educação e Imagem, 2007, v. 1:1027.

de ANDRADE, Nívea. Histórias possíveis entre imagens: conhecimentos e significações na produção de vídeos em escolas. In: MARTINS, Raimundo; TOURINHO, Irene. Processos \& Práticas de Pesquisa em Cultura Visual \& Educação. Santa Maria: Ed. Da UFSM, 2013. p. 135-151.

CERTEAU, Michel de. A invenção do cotidiano - artes de fazer. Petrópólis, RJ:Vozes, 2013.

DELEUZE, Gilles e GUATARRI, Félix. O que é filosofia? Tradução de Bento Prado Jr. E Alberto Alonso Muñoz. São Paulo: Editora 34, 2010 (3aㅡ Edição).

FISCHMAN, Gustavo E. Reflexões sobre imagens, cultura visual e pesquisa educacional. In: ALVES, Nilda e CIAVATTA, Maria (orgs.). A Leitura de Imagens na pesquisa social: história, comunicação e educação. São Paulo: Cortez, 2008.

KOSSOY, Boris. Realidades e ficções na trama fotográfica. São Paulo: Ateliê Ed., 1999.

LOPES, Alice Ribeiro Casimiro. Conhecimento escolar: ciência e cotidiano. Rio de Janeiro: EDUERJ, 1999.

MACHADO, Arlindo. O quarto iconoclasmo e outros ensaios hereges. Rio de Janeiro: Marca d'Água, 2001.

MATURANA, Humberto. Cognição, ciência e vida cotidiana. Belo Horizonte/MG: Ed UFMG, 2001.

OLIVEIRA, Inês Barbosa. Currículos em espaços não escolares: aprendizagens cotidianas e redes de conhecimento para além da escola. In: PARAísO, Marluce; VILELA, Rita Amélia; SALES, Shirlei Rezende (Orgs). Desafios contemporâneos sobre currículo e escola básica. Curitiba, PR: CRV, 2012.

Os Companheiros. Direção: Mario Monicelli. Com: Marcello Mastroianni, Renato Salvatori, Annie Girardot, Folco Lulli, Raffaela Carrà. Itália, França e lugoslávia: 1963. Vídeo MP4, 123 min., drama, preto e branco, legendado. Disponível em https://www.youtube.com/watch?v=d0GFdvd9XBY, acesso em jan. 2015.

RINCÓN, Omar. Televisión, video y subjetividad. Bogotá, Colômbia: Grupo Editorial Norma, 2002. 
SANTOS, Milton. O professor como intelectual na sociedade contemporânea. Conferência de abertura do IX ENCONTRO NACIONAL DE DIDÁTICA E PRATICA DE ENSINO. Águas de Lindóia, SP, 1998.

\section{Imagens}

Imagem 1 - Fonte: Arquivo pessoal das autoras.

Imagem 2 - Disponível em: http://averdade.org.br/2011/09/os-companheiros/. Acesso em maio/2016

Imagem 3 - Disponível em: https://imagensamadas.com/tag/1960/. Acesso em maio/2016.

Imagem $4 \quad$ - $\quad$ Disponível em: http://naufrago-dautopia.blogspot.com.br/2015/04/veja-no-blogue-o-melhor-filme-sobre-o.html. Acesso em maio/2016.

Imagem 5 - Disponível em:

https://fernandonogueiracosta.wordpress.com/2013/02/28/os-filmes-deminha-vida-fase-universitaria-em-belo-horizonte-1971-1974/. Acesso em maio/2016. 